\title{
Water Quality Variation Characteristics in Stormwater Period and on Weihe River Time Scale
}

\author{
Jin Ding ${ }^{1,2 *}$, Huaien $\mathrm{Li}^{3}$, Lan Cuo ${ }^{1,2,4,5}$, Chaolu Yi ${ }^{1,2}$ \\ ${ }^{1}$ University of Chinese Academy of Sciences, Beijing, China. \\ ${ }^{2}$ Institute of Tibetan Plateau Research, Chinese Academy of Sciences, Beijing, China. \\ ${ }^{3}$ State Key Laboratory Base of Eco-Hydraulic Engineering in Arid Area, Xi'an University of Technology, \\ Xi' an 710048, China \\ ${ }^{4}$ Center for Excellence in Tibetan Plateau Earth Sciences, Beijing, China. \\ ${ }^{5}$ Key Laboratory of Tibetan Environment Changes and Land Surface Processes, \\ Institute of Tibetan Plateau Research, Chinese Academy of Sciences,Beijing, China.
}

\author{
Received: 15 March 2017 \\ Accepted: 28 May 2017
}

\begin{abstract}
Based on 2005-15 water quality data and measured flood data in 2006-12 at Tongguan Bridge Section, storm-period water-quality characteristics and different time-scale water-quality characteristics have been analyzed for the Weihe River and its basins. The interannual and quarterly mean concentrations of COD, $\mathrm{NH}_{3}-\mathrm{N}, \mathrm{DO}$, and river $\mathrm{pH}$ value are calculated to evaluate pollution characteristics. Water quality in flood and non-flood periods were monitored to explore the relationship between peak flows and water quality in stormwater. The results showed that in the stormwater period, index concentrations and their fluctuation ranges decreased and were reduced gradually with the increase of peak flow. When peak flow was in the range of $480-680 \mathrm{~m}^{3} / \mathrm{s}$, concentrations of $\mathrm{COD}$ and $\mathrm{NH}_{3}-\mathrm{N}$ had the same trend of increasing and decreasing in general. During 2005-15, river $\mathrm{pH}$ value fluctuated in the range of 7 to 8 , and $\mathrm{pH}$ value in the second quarter was slightly higher than in the other three quarters. Water quality of the Weihe improved significantly after 2010.
\end{abstract}

Keywords: peak flow, river water quality indexes, concentration variation characteristics, Weihe River

\section{Introduction}

Surface water quality is a matter of serious concern today so that the monitoring of environmental parameters is one of the highest priorities in the evaluation of environmental status of water resources and in environmental protection policy [1-2]. There are complex pollution sources of nitrogen $(\mathrm{N})$ discharges into many river basins worldwide [3]. Excess nitrogen export may result in harmful algal blooms and hypoxia adversely affecting biodiversity and fisheries [4]. Water quality and its enhancement have a close connection with the presence of chemical oxygen demand (COD). Oxygen concentration acts as an important indicator of water quality, so hypoxia occurs when waters become undersaturated in dissolved 
oxygen (DO), causing organisms to suffer adverse and potentially lethal effects [5-6]. Consequently, researching variation characteristics of topical pollutants in a river, such as $\mathrm{COD}, \mathrm{NH}_{3}-\mathrm{N}, \mathrm{DO}$, and $\mathrm{pH}$ value, is necessary and useful for watershed management. According to previous research, the concentration of $\mathrm{NH}_{3}-\mathrm{N}$ subjected to runoff volume is high in winter and spring, and mild in summer and autumn [7-9]. COD values fluctuate seasonally [10]. Meantime, hydrology has the greatest influence on $\mathrm{pH}$ [11]. In the Weihe, the concentrations of SS, COD, $\mathrm{TP}$, and $\mathrm{TN}$ in the raw samples from flood events were higher than those from normal discharge events. The peak time of concentration of COD and TN in the raw samples were close to or lagged behind the time of peak flow [12]. The highest concentration of $\mathrm{NH}_{3}-\mathrm{N}$ in the Weihe was in the dry season, which was followed by the mean-flow period and wet season [13-14]. During 2006-10, the average annual rate of COD emissions decline was $5.8 \%$ in the Shanxi Section of the Weihe [15]. Dissolved oxygen (DO) was the main influencing factor to total phosphorus (TP) and total nitrogen (TN) in summer and winter [16]. The dilution effect of high-flow flooding on $\mathrm{NH}_{3}-\mathrm{N}$ was significant [17].

Taking the Weihe River Basin as an example and selecting the Tongguan Bridge Section (TBS; the section where the Weihe flows into the Yellow River) as our research area, depending on water quality monitoring data published by the state and synchronous flood measurement data of TBS, we analyzed the concentration variation characteristics of typical indexes of water quality followed by stormwater and its variation characteristics on different time scales.

\section{Materials and Methods}

\section{Generalization of Study Area}

The Weihe is a primary tributary of the Yellow River. The Weihe's length is $818 \mathrm{~km}$ and its catchment area is 134.8 thousand $\mathrm{km}^{2}$. It flows into the Yellow River at TBS from west to east, and rises north of Niaoshu Mountain in Gansu Province. The climate of the Weihe Basin is continental, warm, and semihumid as controlled by the East Asian monsoon climate [18]. The annual average temperature of the basin is about $13.3^{\circ} \mathrm{C}$ and annual rainfall is in the range of $558-750 \mathrm{~mm}$, with a general increasing trend from north to south. The mean annual precipitation of this basin area is 31.16 billion $\mathrm{m}^{3}$, and about $78 \%$ of the rainfall concentrates during May to October, among which the rainfall from July to September accounts for $47 \%$ of the annual total. The basin elevation increases gradually from east to west. The major soil type is cultivated loessial soils and major land uses include farmland, grassland, and woodland. Downstream of the Weihe Basin is Guanzhong Plain - the main wheat- and cotton-producing area in China and that is intensively irrigated from various surface and groundwater resources [19].

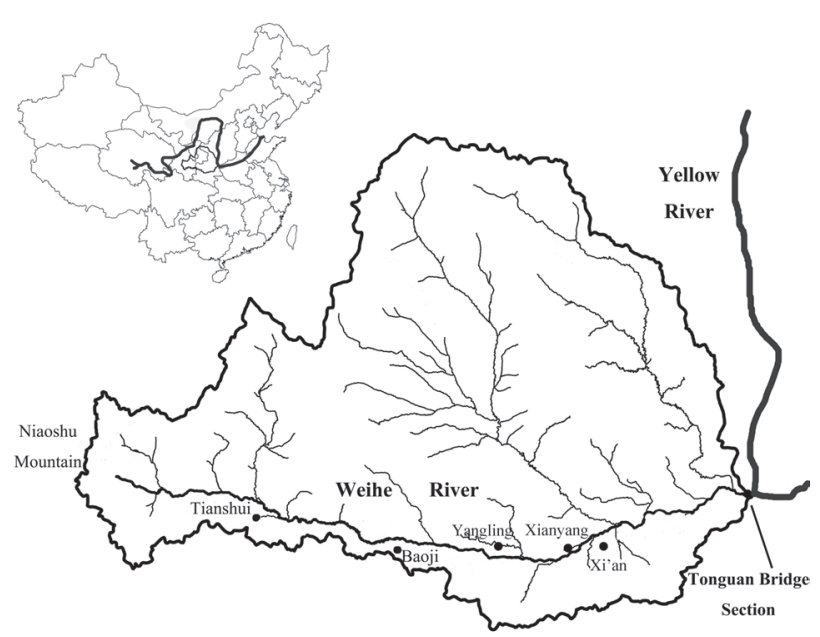

Fig. 1. The Weihe River and Tongguan Bridge Section.

TBS, which is the only important automatic monitoring section in Shaanxi Province set by the Ministry of Environmental Protection of the People's Republic of China, was used to monitor the Weihe, and its basin water quality in the Yellow River Basin, meanwhile, was selected as a control section to research typical pollutant concentrations and river $\mathrm{pH}$ values of the Weihe. All told, the data from TBS can reflect on water quality when the Weihe flows into the Yellow. The location of the Weihe Basin and TBS are shown in Fig. 1.

\section{Study Materials}

TBS water quality data was used to research variation characteristics at time scales of water quality index concentrations, as provided by weekly TBS water quality published by the Ministry of Environmental Protection from February 2005, including four indexes: dissolved oxygen (DO), chemical oxygen demand (COD), ammonia nitrogen $\left(\mathrm{NH}_{3}-\mathrm{N}\right)$, and river $\mathrm{pH}$. DO is a basis of water self-purification ability. When the water is polluted by organics, oxygen is consumed excessively and the anaerobic bacteria that makes water black and smelly will multiply quickly in the water. DO is different from other indexes of water quality as the better the water quality of the river, the greater the value of DO [20]. COD is usually used to indicate the degree of water pollution, and it is also an important indicator of total emissions control [21-22]. Ammonia nitrogen $\left(\mathrm{NH}_{3}-\mathrm{N}\right)$ refers to the presence of free ammonia $\left(\mathrm{NH}_{3}\right)$ and ammonium ions $\left(\mathrm{NH}_{4}^{+}\right)$in the form of nitrogen. $\mathrm{NH}_{3}-\mathrm{N}$ is the nutrient in the water that can cause the phenomenon of eutrophication. It is also toxic to fish and some aquatic organisms as a major oxygenconsuming pollutant. The $\mathrm{pH}$ value used as an indicator of acidity and alkalinity in aqueous solution is one of the most important physical and chemical parameters of aqueous solution.

Flood peak flow data on TBS from 2005 to 2012, used for researching the relationship between peak flow and river water quality, is supplied by extracts of hydrological 
elements of "Hydrological Data of the Yellow River River Basin (2005-12)," including data for eight flood peak flows (2006-07), six flood peak flows in 2008, 11 flood peak flows in 2009, 10 flood peak flows in 2010, eight floods peak flows in 2011, and seven flood peak flows in 2012. Correspondingly, the concentration of water quality indexes at peak flow time were measured by the Department of Environmental Science of Xi'an University of Technology.

According to "Water quality - Determination of the chemical oxygen demand - Dichromate method (GB 11914-89)" in the People's Republic of China, COD concentration was measured by sealed digestion method, in which a water sample was sealed and heated at $165^{\circ} \mathrm{C}$ for 15 20 $\mathrm{min}$ [23]. Due to the sealed situation, volatile organic compounds cannot escape, which ensures results becoming more accurate [24]. Depending on "Water quality - Determination of ammonia nitrogen -Ne ssler's reagent spectrophotometry (HJ 535-2009)" in the People's Republic of China, $\mathrm{NH}_{3}-\mathrm{N}$ concentration was measured by Nessler's reagent colorimetric method [25]. DO concentration and $\mathrm{pH}$ value were measured by a dissolved oxygen-determining meter and $\mathrm{pH}$ tester.

\section{Study Methods}

In terms of river water quality in a storm period, the appropriate time and its water quality index concentration must be found by aiming at peak flows. A scatter diagram reflecting the relationship between peak flows and water quality index concentrations should be shown. Subsequently, the linear fitting equation and correlation coefficient calculated by least square method for long-term variation are necessary to be done as meaningful statistics. The least squares method is used to solve the problem of how to find a reliable value from a set of measurements, which is widely used in data analysis and statistics [36-30].

The principles of the least squares method are:

For a given set of data $\left\{\left(\mathrm{x}_{\mathrm{i}}, \mathrm{y}_{\mathrm{i}}\right),(\mathrm{i}=1,2, \ldots, \mathrm{m})\right\}$ and fitting curve model $\mathrm{y}=\mathrm{f}(\mathrm{x})$, error distance to $i$ is $\mathrm{f}\left(\mathrm{x}_{\mathrm{i}}\right)-\mathrm{y}_{\mathrm{i}}$ and all points sum of squares is:

$$
\sum_{1}^{\mathrm{m}}\left[f\left(x_{i}\right)-y_{i}\right]^{2}
$$

If parameters of Eq. (1) can be obtained, fitting curve $y=f(x)$ can be obtained. $F$ is a function class consisting of polynomials with all times not exceeding $\mathrm{m}$. The value of Eq. (2) should be obtained to make sure that I can reach the minimum ( $\mathrm{min}$ ). The necessary condition of Eq. (3) reaching $\min$ is the value of I partial derivative getting zero, which are as Eq. (4) and Eq. (5) show. Finally, fitting curve $y=f(x)$ can be confirmed after unique solution $a_{k}$ is obtained.

$$
\begin{gathered}
\mathrm{f}_{\mathrm{k}}\left(x_{i}\right)=\sum_{k=0}^{n} a_{k} x_{i}^{k} \in F \\
I=\sum_{i=0}^{m}\left[f_{k}\left(x_{i}\right)-y_{i}\right]^{2}=\sum_{i=0}^{m}\left(\sum_{k=0}^{n} a_{k} x_{i}^{k}-y_{i}\right)^{2}=\min \\
\frac{\partial I}{\partial \mathrm{a}_{j}}=2 \sum_{i=0}^{m}\left(\sum_{k=0}^{n} a_{k} x_{i}^{k}-y_{i}\right) x_{i}^{j}=0 \quad j=0,1, \ldots, n \\
\sum_{k=0}^{\mathrm{n}}\left(\sum_{i=0}^{m} x_{i}^{j+k}\right) a_{k}=\sum_{i=0}^{m} x_{i}^{j} y_{i} \quad j=1,2, \ldots, n
\end{gathered}
$$

Regarding Eq. (2), if $\mathrm{k}=1$, the relationship is regarded as linear fitting; if $\mathrm{k}>1$, it is polynomial fitting. If the function model is a nonlinear function, it should be transformed into a linear form first, and then calculated as the above process.

According to flood peak flows from many years, different ranges of flood peak flow should be divided into different classes to make the trend obvious in different flood classes. The trends of water quality indexes in flood and non-flood periods can be shown though the averages of $\mathrm{COD}, \mathrm{NH}_{3}-\mathrm{N}, \mathrm{DO}$ concentration, and $\mathrm{pH}$ value during July to October and other months. In addition, water quality variation can be seen from the interannual and quarterly means of $\mathrm{COD}, \mathrm{NH}_{3}-\mathrm{N}, \mathrm{DO}$ concentration, and $\mathrm{pH}$ value. Moreover, different indexes in every quarter and each water quality value in different quarters can be observed significantly in line graphs.

\section{Results and Discussion}

\section{Water Quality Variation Characteristics Followed by Peak Flow}

In some cases, the critical characteristics of flooding are hydrochemical parameters related to changes in the chemical composition of water rather than just hydraulic parameters related to the rise in water levels [31].

In order to explore the relationship between water quality on control section and river flood peak flow during a stormwater period, every flood matching corresponding synchronized measured water quality and quantity data in 2005-12 was found from extracts of hydrological elements of "Hydrological Data of the Yellow River River Basin (2005-2012)" to make a scatter diagram with DO concentration, $\mathrm{COD}$ concentration, $\mathrm{NH}_{3}-\mathrm{N}$ concentration, and $\mathrm{pH}$ value and fitting the correlation. From this, the quantitative relationship between peak flow and water quality can be determined. Meanwhile, variation characteristics of pollutants can be analyzed. 
Table 1. Peak flow and corresponding water quality.

\begin{tabular}{|c|c|c|c|c|c|c|c|c|c|c|c|}
\hline Peak time & $\begin{array}{c}\text { Peak flow } \\
\left(\mathrm{m}^{3} / \mathrm{s}\right)\end{array}$ & $\mathrm{pH}$ & $\begin{array}{c}\mathrm{DO} \\
(\mathrm{mg} / \mathrm{L})\end{array}$ & $\begin{array}{l}\text { COD } \\
(\mathrm{mg} / \mathrm{L})\end{array}$ & $\begin{array}{l}\mathrm{NH}_{3}-\mathrm{N} \\
(\mathrm{mg} / \mathrm{L})\end{array}$ & Peak time & $\begin{array}{c}\text { Peak flow } \\
\left(\mathrm{m}^{3} / \mathrm{s}\right)\end{array}$ & $\mathrm{pH}$ & $\begin{array}{c}\mathrm{DO} \\
(\mathrm{mg} / \mathrm{L})\end{array}$ & $\begin{array}{c}\text { COD } \\
(\mathrm{mg} / \mathrm{L})\end{array}$ & $\begin{array}{l}\mathrm{NH}_{3}-\mathrm{N} \\
(\mathrm{mg} / \mathrm{L})\end{array}$ \\
\hline $\begin{array}{c}2006.07 .05 . \\
20: 00\end{array}$ & 208 & 7.73 & 1.35 & 22.00 & 8.27 & 2010.04 .04 & 622 & 7.41 & 4.72 & 9.30 & 10.60 \\
\hline $\begin{array}{c}2006.07 .13 \\
00: 18\end{array}$ & 263 & 7.58 & 0.48 & 15.00 & 5.61 & 2010.06 .06 & 260 & 7.86 & 5.08 & 12.50 & 2.43 \\
\hline $\begin{array}{c}2006.07 .17 \\
16: 00\end{array}$ & 555 & 7.46 & 0.58 & 10.20 & 2.68 & 2010.06 .11 & 419 & 7.48 & 4.10 & 11.20 & 1.23 \\
\hline $\begin{array}{c}2006.07 .26 \\
20: 00\end{array}$ & 267 & 7.52 & 0.89 & 10.30 & 0.96 & 2010.07 .26 & 2218 & 7.84 & 4.15 & 9.00 & 1.08 \\
\hline $\begin{array}{c}2006.08 .17 \\
01: 14\end{array}$ & 615 & 7.61 & 1.12 & 13.30 & 1.56 & $\begin{array}{c}2010.08 .04 \\
07: 30\end{array}$ & 628 & 7.69 & 3.49 & 6.90 & 0.55 \\
\hline $\begin{array}{c}2006.08 .30 \\
16: 20\end{array}$ & 545 & 7.56 & 0.36 & 3.60 & 0.60 & $\begin{array}{c}2010.08 .11 \\
05: 12\end{array}$ & 1478 & 7.61 & 2.33 & 5.10 & 1.04 \\
\hline $\begin{array}{c}2006.09 .03 \\
7: 54 \\
\end{array}$ & 968 & 7.60 & 0.75 & 7.30 & 0.38 & $\begin{array}{c}2010.08 .13 \\
23: 42\end{array}$ & 1407 & 7.68 & 2.89 & 7.40 & 1.90 \\
\hline $\begin{array}{c}2006.09 .29 \\
11: 36\end{array}$ & 919 & 7.59 & 0.40 & 7.70 & 0.37 & $\begin{array}{c}2010.08 .25 \\
19: 06\end{array}$ & 2230 & 7.65 & 4.14 & 8.70 & 0.26 \\
\hline $\begin{array}{c}2007.07 .22 \\
02: 50\end{array}$ & 945 & 7.77 & 0.23 & 9.20 & 5.15 & $\begin{array}{c}2010.09 .06 \\
03: 18\end{array}$ & 586 & 7.61 & 3.69 & 8.60 & 1.21 \\
\hline $\begin{array}{c}2007.07 .27 \\
13: 42\end{array}$ & 662 & 7.65 & 0.18 & 9.80 & 1.91 & $\begin{array}{c}2010.09 .11 \\
08: 00\end{array}$ & 1310 & 7.88 & 2.23 & 8.50 & 1.02 \\
\hline $\begin{array}{c}2007.07 .31 \\
00: 30\end{array}$ & 1076 & 7.95 & 0.19 & 7.80 & 0.92 & $\begin{array}{c}2011.07 .10 \\
10: 48\end{array}$ & 464 & 7.87 & 3.72 & 6.00 & 3.65 \\
\hline $\begin{array}{c}2007.08 .09 \\
16: 54\end{array}$ & 598 & 7.45 & 0.19 & 9.10 & 1.22 & $\begin{array}{c}2011.08 .02 \\
14: 18\end{array}$ & 877 & 8.15 & 4.85 & 8.00 & 2.61 \\
\hline $\begin{array}{c}2007.08 .11 . \\
08: 00\end{array}$ & 1840 & 7.33 & 0.20 & 5.30 & 0.21 & $\begin{array}{c}2011.08 .07 \\
08: 36\end{array}$ & 589 & 7.82 & 4.39 & 6.30 & 0.92 \\
\hline $\begin{array}{c}2007.09 .01 \\
18: 48\end{array}$ & 1205 & 7.46 & 0.20 & 7.40 & 0.93 & $\begin{array}{c}2011.08 .23 \\
15: 12\end{array}$ & 756 & 7.84 & 2.39 & 5.70 & 0.59 \\
\hline $\begin{array}{c}2007.10 .09 \\
7: 54\end{array}$ & 1033 & 7.95 & 0.14 & 7.60 & 0.87 & $\begin{array}{c}2011.09 .09 \\
02: 00\end{array}$ & 2177 & 7.93 & 3.42 & 4.10 & 0.47 \\
\hline $\begin{array}{c}2007.10 .15 . \\
00: 00\end{array}$ & 929 & 8.03 & 3.50 & 9.30 & 1.08 & $\begin{array}{c}2011.09 .14 \\
02: 30\end{array}$ & 2180 & 7.98 & 3.22 & 4.50 & 0.64 \\
\hline $\begin{array}{c}2008.07 .23 \\
17: 36\end{array}$ & 948 & 6.36 & 2.03 & 5.60 & 1.66 & $\begin{array}{c}2011.09 .20 \\
19: 12\end{array}$ & 5286 & 7.97 & 4.04 & 3.60 & 0.72 \\
\hline $\begin{array}{c}2008.08 .11 \\
02: 12\end{array}$ & 250 & 7.28 & 2.24 & 10.90 & 1.96 & $\begin{array}{c}2011.09 .30 \\
12: 24\end{array}$ & 997 & 8.00 & 4.98 & 6.00 & 0.63 \\
\hline $\begin{array}{c}2008.08 .18 \\
11: 42\end{array}$ & 461 & 7.27 & 2.84 & 9.40 & 1.49 & $\begin{array}{c}2012.07 .04 \\
07: 42\end{array}$ & 242 & 8.19 & 6.11 & 8.60 & 1.48 \\
\hline $\begin{array}{c}2008.08 .30 \\
13: 54\end{array}$ & 475 & 7.29 & 3.38 & 8.80 & 1.79 & $\begin{array}{c}2012.07 .11 \\
20: 06\end{array}$ & 452 & 7.70 & 3.15 & 5.50 & 3.12 \\
\hline $\begin{array}{c}2008.09 .04 \\
10: 30\end{array}$ & 152 & 7.78 & 4.80 & 7.30 & 2.31 & $\begin{array}{c}2012.07 .23 \\
22: 54\end{array}$ & 704 & 8.23 & 6.25 & 5.10 & 0.53 \\
\hline $\begin{array}{c}2008.09 .30 \\
16: 00\end{array}$ & 807 & 7.14 & 4.13 & 5.55 & 1.66 & $\begin{array}{c}2012.08 .20 \\
11: 18\end{array}$ & 1193 & 8.05 & 4.65 & 4.60 & 0.42 \\
\hline $\begin{array}{c}2009.05 .13 \\
12: 40\end{array}$ & 363 & 7.57 & 4.77 & 10.70 & 6.45 & $\begin{array}{c}2012.09 .03 \\
03: 18\end{array}$ & 2302 & 7.93 & 5.08 & 3.90 & 0.56 \\
\hline $\begin{array}{c}2009.05 .16 \\
20: 36\end{array}$ & 549 & 8.09 & 5.05 & 8.30 & 4.77 & $\begin{array}{c}2012.09 .09 \\
18: 54\end{array}$ & 603 & 7.97 & 5.56 & 5.60 & 0.45 \\
\hline $\begin{array}{c}2009.07 .22 \\
20: 00\end{array}$ & 301 & 7.73 & 2.84 & 6.20 & 4.17 & $\begin{array}{c}2012.09 .13 \\
00: 24\end{array}$ & 940 & 7.82 & 4.46 & 3.50 & 0.60 \\
\hline $\begin{array}{c}2009.07 .29 \\
04: 00\end{array}$ & 191 & 7.58 & 2.56 & 5.80 & 7.32 & & & & & & \\
\hline
\end{tabular}


Table 1. Continued.

\begin{tabular}{|c|c|c|c|c|c|l|l|l|l|l|l|}
\hline $\begin{array}{c}2009.08 .06 . \\
00: 36\end{array}$ & 740 & 7.30 & 3.29 & 5.50 & 2.90 & & & & & & \\
\hline $\begin{array}{c}2009.08 .18 . \\
18: 18\end{array}$ & 443 & 7.80 & 1.36 & 6.60 & 2.02 & & & & & & \\
\hline $\begin{array}{c}2009.08 .21 . \\
07: 24\end{array}$ & 665 & 7.57 & 1.52 & 5.10 & 1.45 & & & & & & \\
\hline $\begin{array}{c}2009.08 .31 . \\
07: 12\end{array}$ & 1174 & 7.81 & 1.87 & 4.70 & 1.79 & & & & & & \\
\hline $\begin{array}{c}2009.09 .11 . \\
00: 00\end{array}$ & 232 & 7.72 & 2.98 & 4.30 & 2.42 & & & & & & \\
\hline $\begin{array}{c}2009.09 .16 . \\
05: 30\end{array}$ & 1010 & 7.64 & 2.83 & 4.70 & 1.66 & & & & & & \\
\hline $\begin{array}{c}2009.09 .22 . \\
00: 00\end{array}$ & 757 & 7.50 & 3.53 & 5.10 & 1.74 & & & & & & \\
\hline
\end{tabular}

As can be seen from Fig. 2(a-b), as river flood peak approaches, concentrations of $\mathrm{COD}$ and $\mathrm{NH}_{3}-\mathrm{N}$ were in the range of $2-16 \mathrm{mg} / \mathrm{L}$ and $0-8 \mathrm{mg} / \mathrm{L}$. Meanwhile, concentrations of $\mathrm{COD}$ and $\mathrm{NH}_{3}-\mathrm{N}$ decreased first with the increase of the peak flow, then with the increase of the peak flow, COD in progressive and NH3-N concentration approached to infinitely low.

Fig. 2c) shows that the Weihe, whose $\mathrm{pH}$ value was between 7 and 8.5 , was weakly alkaline during the peak coming in the river. And river $\mathrm{pH}$ value did not change regularly with peak flow, which was showed by the very small $\mathrm{R}^{2}$ of the fitting curve. As can be seen from Fig. 2d), there was no apparent fitting relationship between peak flow and DO concentration. When peak flow was under $2,000 \mathrm{~m}^{3} / \mathrm{s}$, DO concentration was in the range of $0 \sim 7 \mathrm{mg} / \mathrm{L}$. On the other hand, when peak flow was more than $2,000 \mathrm{~m}^{3} / \mathrm{s}$, corresponding DO concentration was higher than usual.

In order to analyze the relationship between concentration of water quality indexes and different peak flows, through observing fluctuation range and variation characteristics of indexes of water quality concentration in different peak flow ranges, all floods in 2006-12 should be graded according to the peak flow size. Floods in TBS grading result and corresponding concentration range of typical pollutants were shown in Table 2. The changing trend of typical water quality index concentrations following flow are shown in Fig. 3.

As can be seen in Table 2 and Fig. 3, when peak flow was $150-400 \mathrm{~m}^{3} / \mathrm{s}$, the concentrations of COD and a)

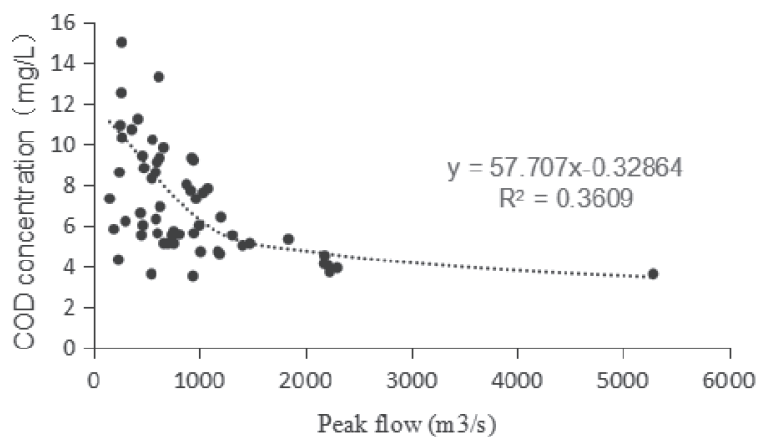

b)

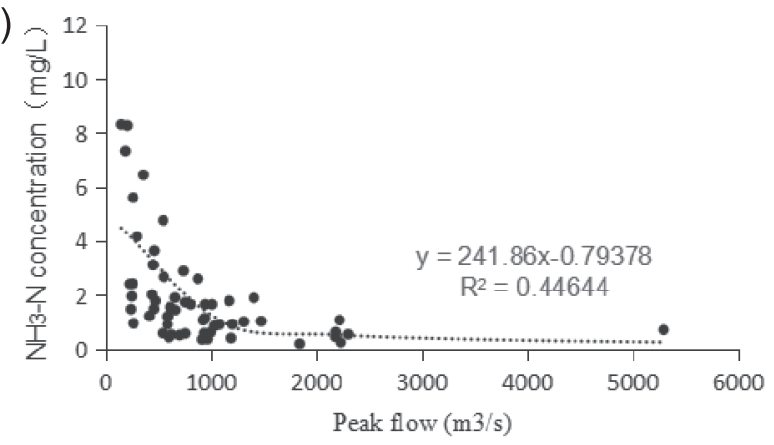

c)

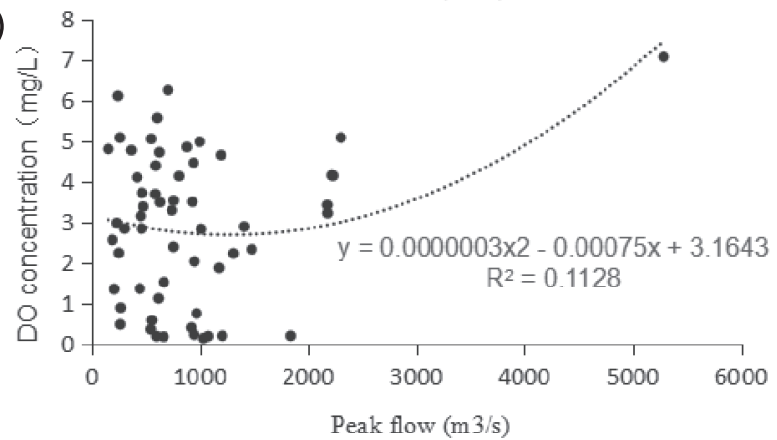

d)

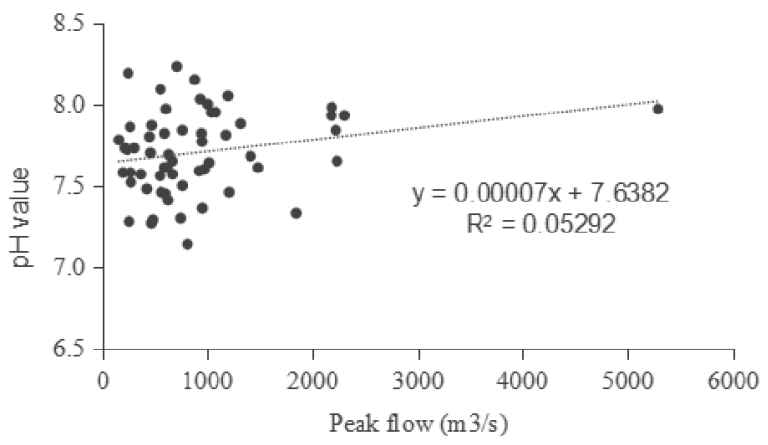

Fig. 2. Relationship between peak flow and water quality. 
Table 2. Water quality concentration ranges in different ranges of peak level.

\begin{tabular}{|c|c|c|}
\hline $\begin{array}{c}\text { Range of peak flow } \\
\left(\mathrm{m}^{3} / \mathrm{s}\right)\end{array}$ & $\mathrm{COD}_{\mathrm{Mn}}(\mathrm{mg} / \mathrm{L})$ & $\mathrm{NH}_{3}-\mathrm{N}(\mathrm{mg} / \mathrm{L})$ \\
\hline $140 \sim 380$ & $4.30-22.00$ & $0.96-8.30$ \\
\hline $400 \sim 600$ & $3.60-11.20$ & $0.60-4.77$ \\
\hline $600 \sim 780$ & $5.10-13.30$ & $0.45-2.90$ \\
\hline $800 \sim 1,000$ & $3.50-9.30$ & $0.37-2.61$ \\
\hline $1,000 \sim 1,800$ & $4.60-7.80$ & $0.21-1.90$ \\
\hline More than 2,100 & $3.60-4.10$ & $0.26-1.08$ \\
\hline
\end{tabular}

$\mathrm{NH}_{3}-\mathrm{N}$ were in the range of $3 \sim 18 \mathrm{mg} / \mathrm{L}$ and $0.5 \sim 3 \mathrm{mg} / \mathrm{L}$; when peak flow was $600-800 \mathrm{~m}^{3} / \mathrm{s}$, their concentrations were in the range of $5 \sim 13 \mathrm{mg} / \mathrm{L}$ and $0.45 \sim 2.9 \mathrm{mg} / \mathrm{L}$; when peak flow was more than $2,000 \mathrm{~m}^{3} / \mathrm{s}$, their concentrations were in the range of $3.5 \sim 4 \mathrm{mg} / \mathrm{L}$ and $0.2 \sim 1 \mathrm{mg} / \mathrm{L}$. These showed that with the increase of the

a)

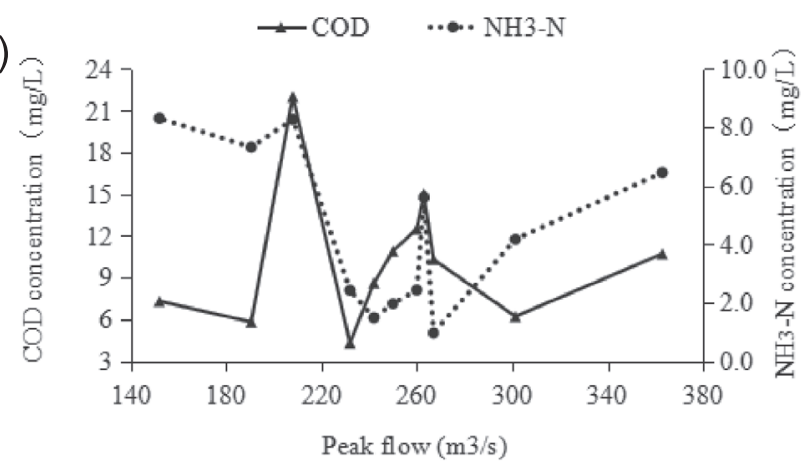

b)

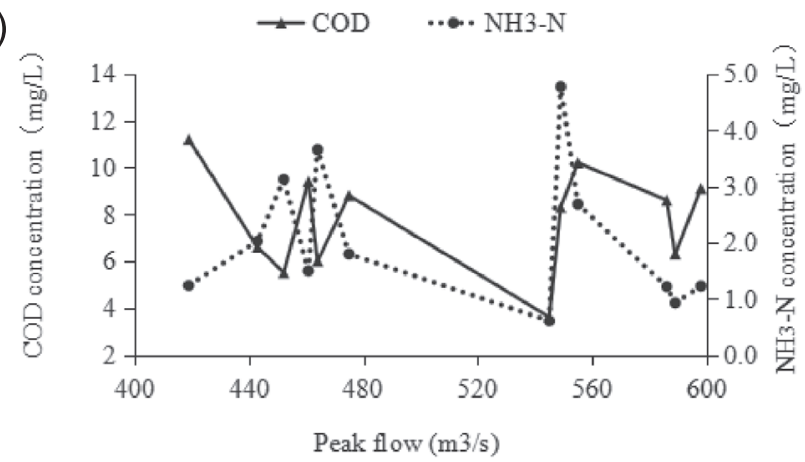

c)

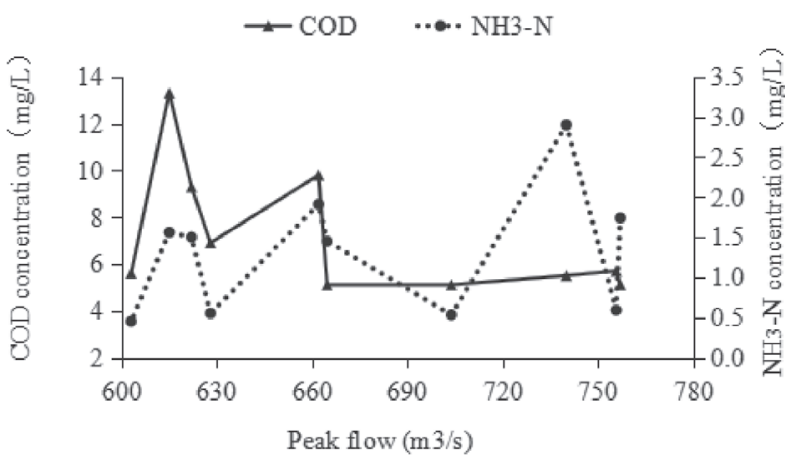

peak flow, indexes of water quality concentration in TBS were decreased gradually and the fluctuation range of indexes of water quality concentration in TBS were also reduced gradually.

In addition, as can be seen from Fig. 3(b-c), when peak flow belongs to the medium flow in the range of $480 \sim 680 \mathrm{~m}^{3} / \mathrm{s}$, the concentrations of $\mathrm{COD}$ and $\mathrm{NH}_{3}-\mathrm{N}$ had the same change trend of increase and decrease in general.

\section{Characteristics in Flood and Non-Flood Period of Water Quality Indexes}

For exploring the variation and differences of DO, $\mathrm{COD}, \mathrm{NH}_{3}-\mathrm{N}$ concentration, and $\mathrm{pH}$ value in flood and non-flood periods, water quality data of TBS from July to October in every year was regarded as flood period data, and the other months' data in every year was taken as non-flood periods. Then the water quality index concentration values of flood and nonflood periods were averaged in every year as the annual d)

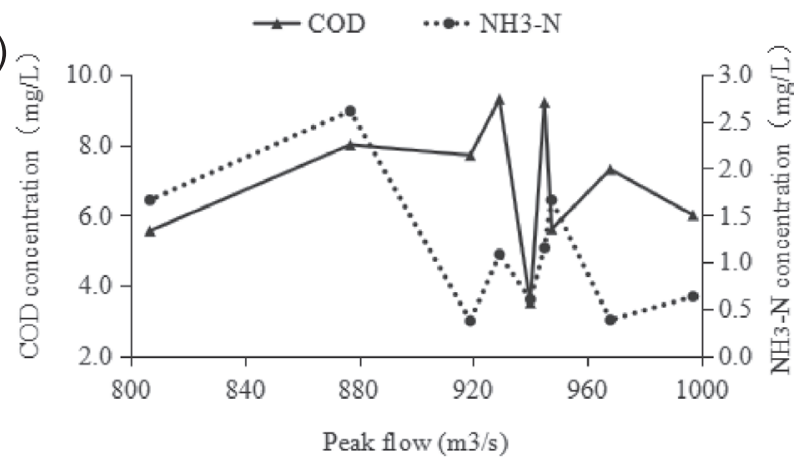

e)

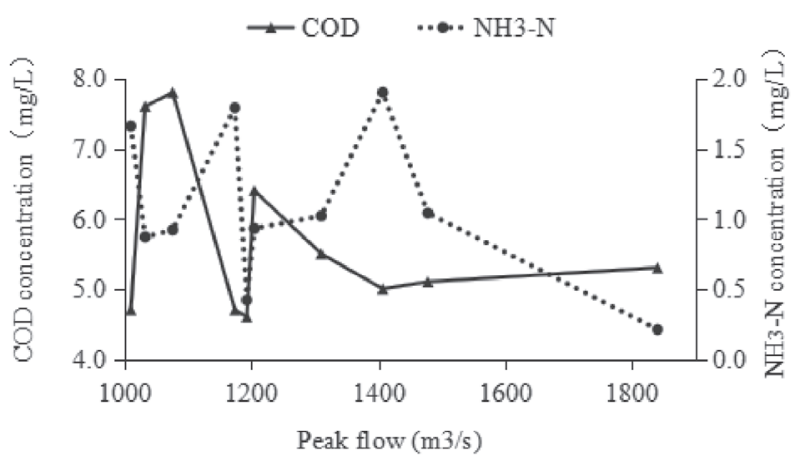

f)

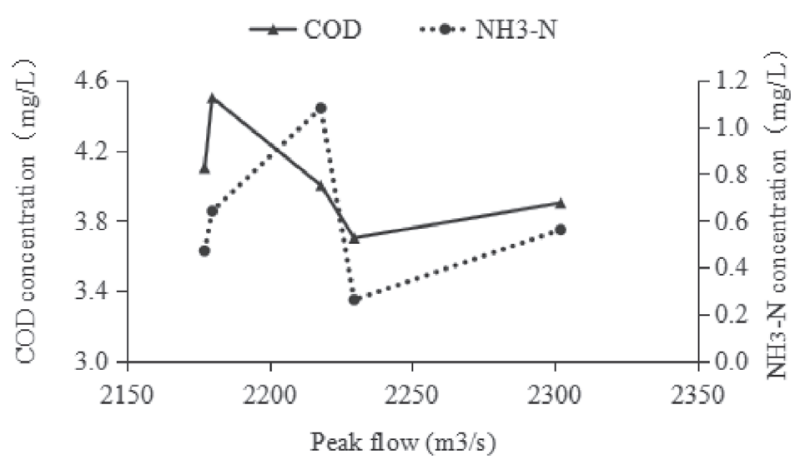

Fig. 3. Relationships between index concentrations and different ranges of peak flow. 
mean value in flood and non-flood periods. The results of annual mean value and its change trend are shown in Fig. 4.

As can be seen in Fig. 4(a-b), water quality index concentrations in the non-flood period were higher than in the flood period. During 2005-15, the nonflood period concentration of $\mathrm{COD}$ and $\mathrm{NH}_{3}-\mathrm{N}$ showed a significant drop, and $\mathrm{COD}$ and $\mathrm{NH}_{3}-\mathrm{N}$ concentration decreased from $30 \mathrm{mg} / \mathrm{L}$ to $10 \mathrm{mg} / \mathrm{L}$, and from $5 \sim 8 \mathrm{mg} / \mathrm{L}$ to less than $2 \mathrm{mg} / \mathrm{L}$. COD flood period concentration decreased year by year from 2006 to 2012, and then had a small rebound; after 2010, the flood period concentration

a)

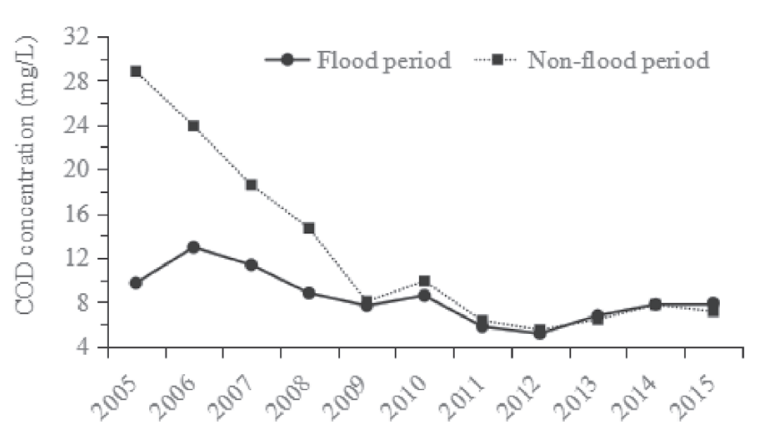

b)

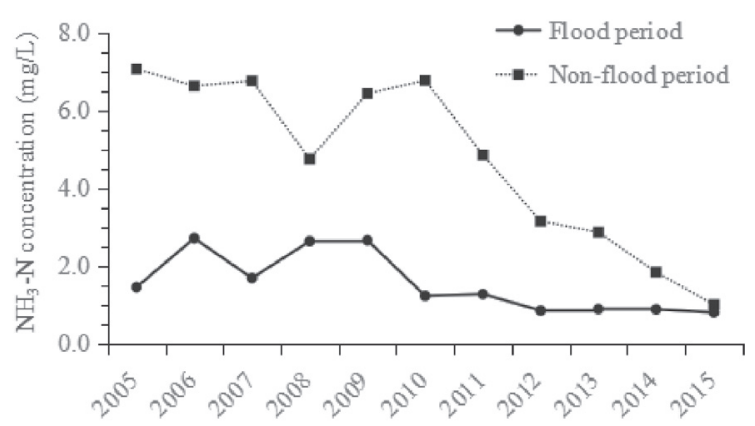

c)

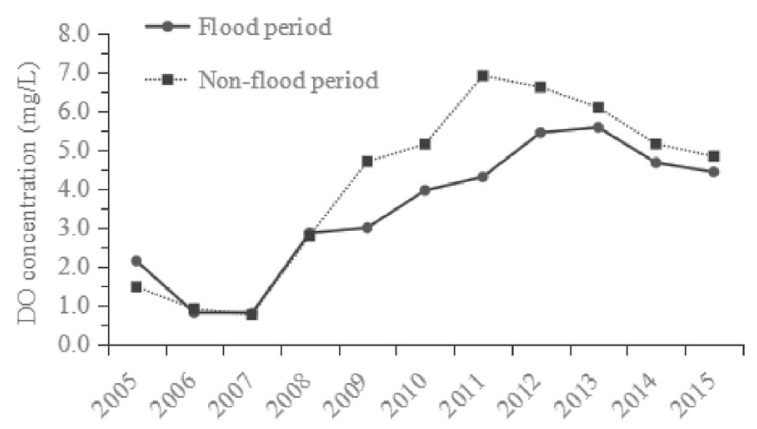

d)

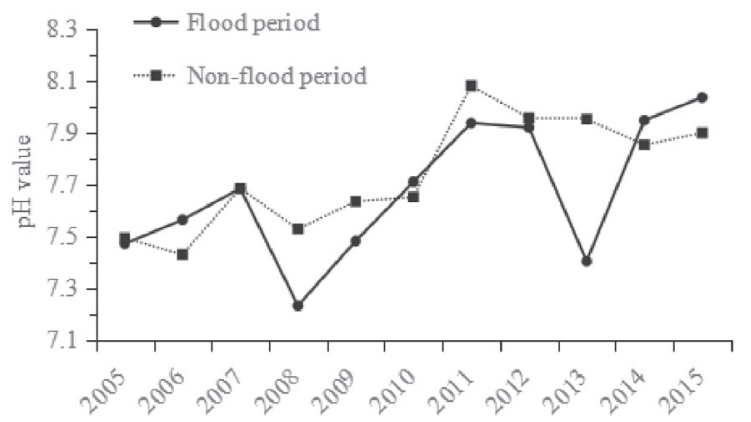

Fig. 4. Variation trend of water quality index concentrations in flood and non-flood periods. of $\mathrm{NH}_{3}-\mathrm{N}$ was significantly lower than in non-flood periods before 2010 .

Fig. 4c) shows that DO concentration variation trends in flood and non-flood periods were roughly the same, as they both had an obvious rise after 2007; DO non-flood period concentration increased more evidently than in flood periods in the study years, which means DO concentration in base flow of the Weihe significantly increased. As can be seen from Fig. 4d), river $\mathrm{pH}$ value on TBS had a fluctuation between 7 and 8 in both flood and nonflood periods. Meanwhile, the fluctuation of $\mathrm{pH}$ value in the flood period was more evident than in the non-flood period.
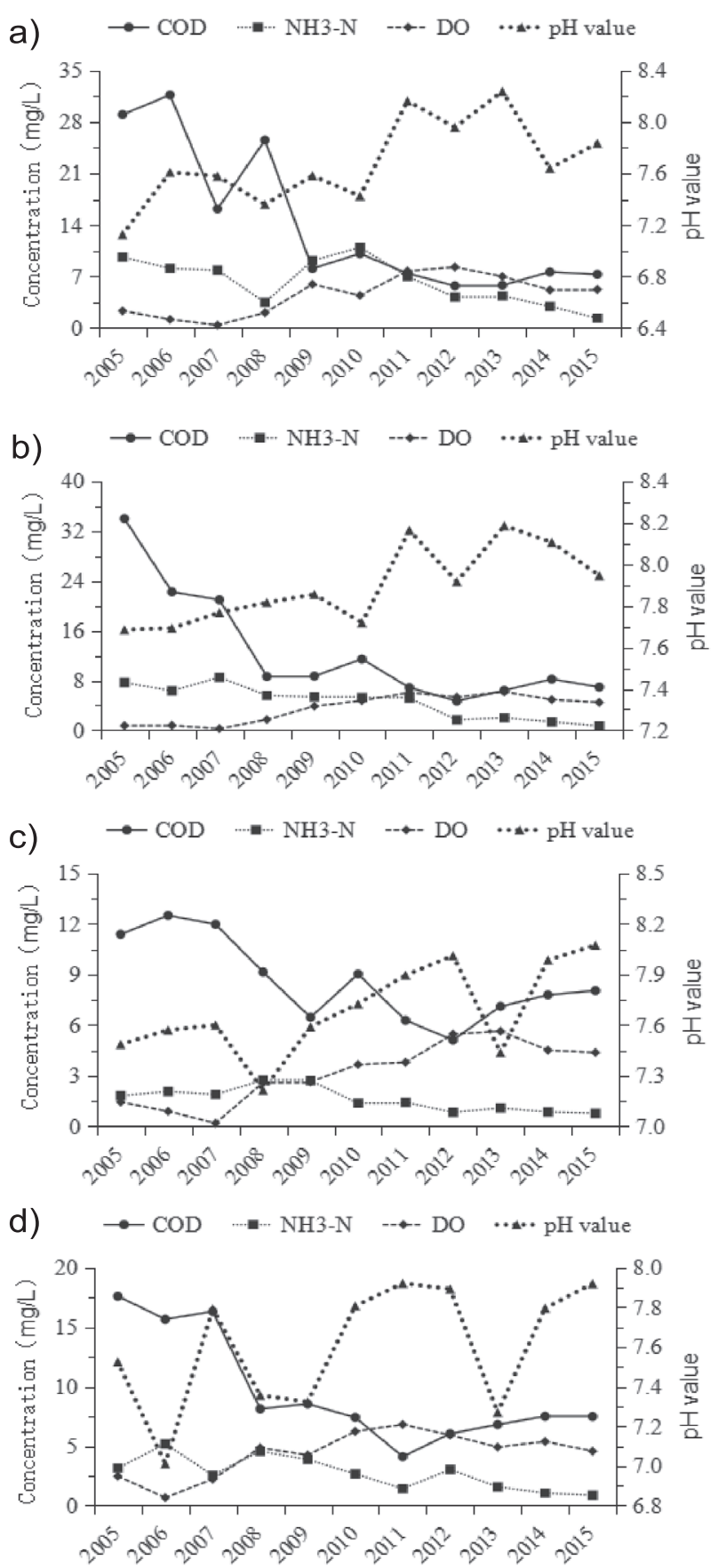

Fig. 5. Water quality in different quarters. 


\section{Water Quality Variation Characteristics on Time Scales}

\section{Quarterly Variation of Water Quality Indexes}

In order to research the quarterly variation characteristics of water quality index concentrations on TBS, the concentrations from February to April were taken as first-quarter concentration, concentrations from May to July were taken as second-quarter concentration, concentrations from August to October were taken as third-quarter concentration, and concentrations from November to the following January were taken as fourth-quarter concentration. Subsequently, based on all

a)

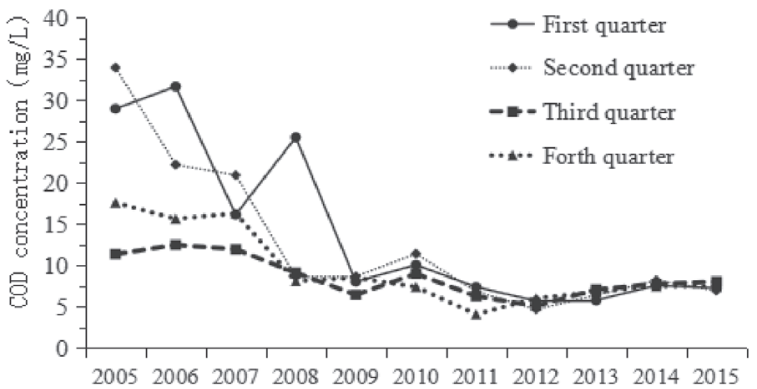

b)

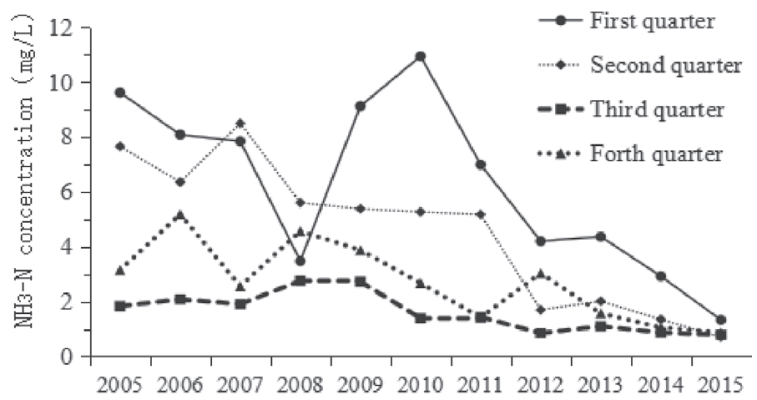

c)

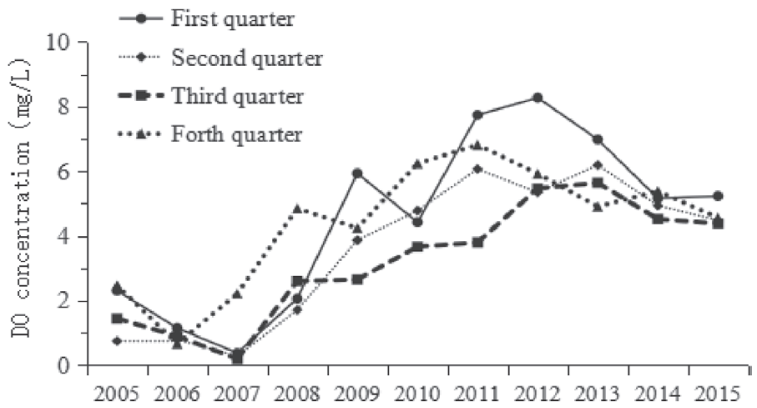

d)

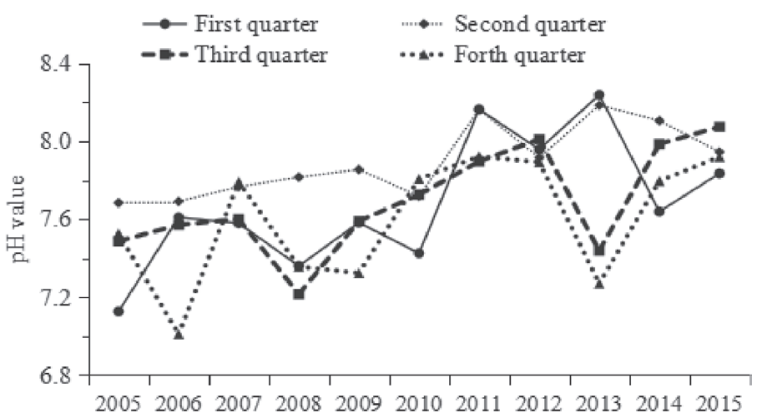

Fig. 6. Index concentration characteristics in different quarters. weeks, water quality data in every quarter of every year, concentration average value of indexes of water quality in every quarter were calculated and then the variation characteristics of index of water quality concentration in different quarters could be analyzed (Fig. 5); different water quality index variation trends in the same quarter also could be researched (Fig. 6).

As can be seen from Fig. 5, in each year after 2010 the concentration of $\mathrm{COD}$ and $\mathrm{NH}_{3}-\mathrm{N}$ had an obvious decrease. At the same time, the DO concentration and river alkalinity had an obvious rise, which meant Weihe water quality in the first and second quarters saw evident improvement after 2010. In addition, river alkalinity had an obvious rise after 2010. Compared with the first two quarters, the concentration of $\mathrm{COD}$ and $\mathrm{NH}_{3}-\mathrm{N}$ had a decrease - but not an obvious one - in the third quarter, indicating a flood period. In the fourth quarter, DO concentration had an obvious increase, which was possibly caused by the high solubility of gases in winter, and $\mathrm{NH}_{3}-\mathrm{N}$ concentration had a trend of decreasing year by year after 2008. In the meantime, COD concentration after 2008 was significantly lower than before 2008 .

As can be seen from Fig. 6:

Variation trends of COD concentrations in different quarters were roughly the same, especially after 2009 , and their fluctuation trends were very similar; COD concentration in the first quarter fluctuated more obviously than in the other three quarters.

Fluctuation range of $\mathrm{NH}_{3}-\mathrm{N}$ concentration in the first quarter was larger than in the other three quarters. In addition, $\mathrm{NH}_{3}-\mathrm{N}$ concentration in the third quarter was the highest, which means $\mathrm{NH}_{3}-\mathrm{N}$ concentration was significantly affected by runoff.

$\mathrm{pH}$ value on TBS in the second quarter was slightly higher than the other three quarters, and comparing with the other three quarters, simultaneously, $\mathrm{pH}$ value on TBS in the second quarter fluctuation amplitude was very small.

Changes in DO concentrations in all four quarters had a roughly similar trend.

Therefore, the concentration variation ranges of $\mathrm{NH}_{3}-\mathrm{N}, \mathrm{COD}$, and $\mathrm{DO}$ in the first quarter were obviously greater than in the other quarters. Although the concentration variation of COD and DO was not influenced significantly by variation of quarter, $\mathrm{NH}_{3}-\mathrm{N}$ concentration was significantly affected by quarter, which showed that the more runoff in the quarter, the lower the $\mathrm{NH}_{3}-\mathrm{N}$ concentration.

\section{Interannual Variation Characteristics of Water Quality}

The water quality of all 52 weeks (44 weeks in 2005) in each year from 2005 to 2015 at TBS were averaged as annual average of indexes of water quality in order to research the trend of interannual variation of water quality. The results are shown in Fig. 7.

As can be seen in Fig. 7, pH value on TBS during 2005 to 2015 was between 7 and 8, which meant the 


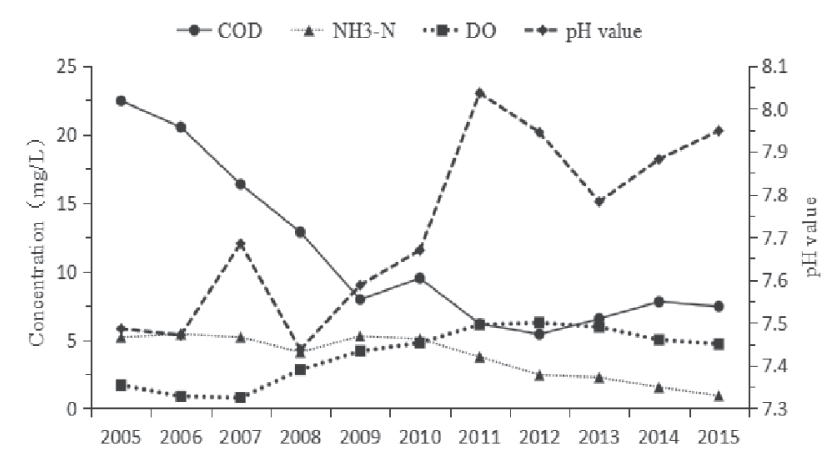

Fig. 7. The average concentration of water quality indexes on TBS.

Weihe was weakly alkaline at the time of flowing into the Yellow. Weihe $\mathrm{pH}$ before 2010 was lower than after 2010. During 2005 to 2012, COD concentration had an obvious downward trend, decreasing from nearly $25 \mathrm{mg} / \mathrm{L}$ to nearly $5 \mathrm{mg} / \mathrm{L}$. Although COD concentration rebounded slightly in 2012-14, it was still under $10 \mathrm{mg} / \mathrm{L}$. $\mathrm{NH}_{3}-\mathrm{N}$ concentration on control section roughly showed a downward trend year by year after 2009. A study by Wang [32] also showed that the concentrations of COD and $\mathrm{NH}_{3}-\mathrm{N}$ were decreasing year by year from 2007 to 2011 . There was a marked rise of DO concentration at TBS from 2007 to 2012. It was visible that, in recent years, the pollution control taken by relevant departments of the Weihe administration was effective.

\section{Variation of Water Quality Class}

Referring to "Environmental Quality Standards for Surface Water," (Table 3), water quality at TBS can be seen:

1. When flood peaks were approaching, COD concentration was kept in the range of water quality class I-II; with the increasing peak flow, COD concentration trended to class I. When peak flow was more than $1,000 \mathrm{~m}^{3} / \mathrm{s}, \mathrm{NH}_{3}-\mathrm{N}$ concentration could be kept under class $\mathrm{V}$, and the higher the peak flow, the closer the $\mathrm{NH}_{3}-\mathrm{N}$ concentration reached the class. $\mathrm{NH}_{3}-\mathrm{N}$ concentration was higher than the standard of class $\mathrm{V}$, when peak flow was under $1,000 \mathrm{~m}^{3} / \mathrm{s}$.

2. During the flood period, COD concentration can reach the standard of class I or class II; during the non-flood period, COD concentration improved from class IV in 2005 to class I in 2008 and was kept at the class until 2015. $\mathrm{NH}_{3}-\mathrm{N}$ flood period concentration belonged to the standard of class V and even worse before 2010, and it improved to class IV after 2010; during the nonflood period in 2005-13, though $\mathrm{NH}_{3}-\mathrm{N}$ concentration was in a declining state it remained at the standard of poor class V. During 2005-07, DO concentration remained at the standard of poor class $\mathrm{V}$, and then $\mathrm{DO}$ concentration increased year by year so that after 2010 in both flood and non-flood periods DO concentration could reach the standard of class I or class II.

3. This can be seen from the annual average of concentration and $\mathrm{pH}$ value: In addition to COD concentration in 2005-07 in the standard of class III or class IV, COD concentration in the following several years reached the standard of class I or class II. In addition, $\mathrm{NH}_{3}-\mathrm{N}$ concentration remained in the standard of poor class V, and until 2014-15 it reached the standard of class IV or class V. During 2005-07, DO concentration remained at the standard of poor class V, then increased in 2008 and reached class III every year after 2009 .

\section{Discussion}

1. In the period of huge rainfall and runoff, the concentrations of $\mathrm{COD}$ and $\mathrm{NH}_{3}-\mathrm{N}$ were generally lower, mainly because the increase of rainfall and runoff made diluted pollutant concentrations. Li [33] and Yang [34] also showed that in the Shanxi section of the Weihe, the concentration of $\mathrm{NH}_{3}-\mathrm{N}$ in the dry season was significantly higher than in the wet period, and COD concentration was not obviously affected by runoff; the average concentration of nitrogen was negatively correlated with rainfall, duration of rainfall, maximum rainfall intensity, and average rainfall intensity. In the dry season, runoff from the Minjiang River is small and the density of $\mathrm{NH}_{3}-\mathrm{N}$ is high - in contrast to the rainy season [35]. Also, in main stream of the Zhujiang River, higher total contaminant concentrations were observed in samples collected in the dry season compared to those in the wet season [36]. Anna [37] seemingly found the reason why few flood events are responsible for nearly $60 \%$ of the total annual $\mathrm{N}$ load: because when most of the basin is covered by vegetation, soils are generally wet, and runoff generation is mainly due to "saturation excess" in wet season.

2. In different quarters, water quality index concentrations have different variation ranges. Between March and May, the ratio of total nitrogen (TN)/total phosphorus

Table 3. Standard for surface water environmental quality standards $(\mathrm{mg} / \mathrm{L})$.

\begin{tabular}{|c|c|c|c|c|c|}
\hline & Class I & Class II & Class III & Class IV & Class V \\
\hline Chemical oxygen demand (COD) & 15 & 15 & 20 & 30 & 40 \\
\hline Ammonia nitrogen $\left(\mathrm{NH}_{3}-\mathrm{N}\right)$ & 0.15 & 0.5 & 1.0 & 1.5 & 2.0 \\
\hline Dissolved oxygen (DO) & 7.5 & 6 & 5 & 3 & 2 \\
\hline
\end{tabular}


(TP) was different from other months [38]. The $\mathrm{N}$ input of wet deposition during the rainy season could not be neglected in the basin ecosystem [39]. Especially DO concentration in the fourth quarter is remarkably higher than in the other quarters, which is similar to the result that DO concentration is significantly correlated with seasons, and the highest concentration is in winter [40]. Also, the low DO values in summer were possibly due to high water temperature and considerable activities of microorganisms, which consumed oxygen as a result of metabolizing activities and the decay of organic matter [41].

3. Weihe water quality saw obvious improvement after 2010. Li [33] also showed that the comprehensive pollution index of the Weihe had been decreasing from nearly 20 in 2010 to less than 20 . Theoretically, if COD concentration is higher, then the water is considered polluted - especially organic pollution [42-43]. And industrial activities can lead to high COD concentration [44-47]. However, because of a series of programs issued by the government (including "Action Plan of Weihe Basin Water Pollution Prevention and Control in three years (2012-2014)"), the emission of pollutants by industrial and other forms of pollution activities were controlled. Meanwhile, wastewater treatment capacity improved.

\section{Conclusions}

1. With the increase of peak flow, not only water quality index concentrations on TBS decreased gradually, but also their fluctuation range was reduced gradually. When peak flow belonged to medium flow, 480 $680 \mathrm{~m}^{3} / \mathrm{s}$, the concentrations of $\mathrm{COD}$ and $\mathrm{NH}_{3}-\mathrm{N}$ had the same change trend, which was the same trend of increase and decrease in general.

2. In the period of huge rainfall and runoff, the concentrations of $\mathrm{COD}$ and $\mathrm{NH}_{3}-\mathrm{N}$ were generally lower than their concentrations in the period of light rainfall and runoff.

3. Concentration fluctuation range of $\mathrm{COD}$ and $\mathrm{NH}_{3}-\mathrm{N}$ in the first quarter was larger than in other quarters. River $\mathrm{pH}$ value at TBS in the second quarter was slightly higher and had a more stable fluctuation than in the other three quarters.

4. Weihe River water quality improved significantly after 2010, which was shown by the evident concentration increase of DO and the evident concentration decrease of $\mathrm{COD}$ and $\mathrm{NH}_{3}-\mathrm{N}$.

\section{Acknowledgements}

This research was financially supported by the Major National Science and Technology Water Project of China (2009ZX07212-002-005-002) and the National Water Resources Protection Plan Related Topics Research Projects (No. Environment 0202042012-2).

\section{References}

1. HOVHANNISYAN ARPINR, SHAHNAZARYAN GAYANE. Determination of background concentrations of hydrochemical parameters and water quality assessment in the Akhuryan River Basin (Armenia). Physics and Chemistry of the Earth Parts A/B/C, 94, 2, 2016.

2. LOUKAS, A. Surface water quantity and quality assessment in pinios river, thessaly, greece, Desalination 250 (1), 266, 2010.

3. YANG X., LIU Q., FU G., HE Y., LUO X., ZHENG Z. Spatiotemporal patterns and source attribution of nitrogen load in a river basin with complex pollution sources. Water research, 94, 187, 2016.

4. HARRY BLAAS, CAROLIEN KROEZE. Excessive nitrogen and phosphorus in european rivers: 2000-2050. Ecological Indicators, 67, 328, 2016.

5. HANBAY D., BAYLAR A., BATAN M. Prediction of aeration efficiency on stepped cascades by using least square support vector machines. Expert Systems with Applications, 36 (3), 4248, 2009.

6. RABALAIS N.N., DIAZ R.J., LEVIN L.A., TURNER R.E., GILBERT D., ZHANG J. Dynamics and distribution of natural and human-caused hypoxia. Biogeosciences, 7 (2), 585,2010 .

7. YU B., HUANG C.M., LIU Z.H., ZHANG B., QIN F.C. Wavelet analysis on nh3-n pollution index changes of the middle-upper minjiang river during last 6 years. Procedia Environmental Sciences, 2 (1), 9, 2010.

8. LI YINGJIE-ZHANG ZHENWEN-WANG YAPINGZHANG QIAN-ZHANG BEI. Water Pollution Condition and Prevention Countermeasures in Guanzhong Section of Weihe River. Yellow River, 37 (6), 53, 2015 [In Chinese].

9. INOUE T., EBISE, S. Runoff characteristics of cod, bod, c, $\mathrm{n}$ and $\mathrm{p}$ loadings from rivers to enclosed coastal seas. Marine Pollution Bulletin, 23 (91), 11, 1991.

10. BELLOS D., SAWIDIS, T. Chemical pollution monitoring of the river pinios (thessalia - greece). Journal of Environmental Management, 76 (4), 282, 2005.

11. CEREO C.F., THREADGILL T., NOEL M.R., HINZ S. Modeling the ph in the tidal fresh potomac river under conditions of varying hydrology and loads. Ecological Modelling, 257 (257), 101, 2013.

12. JIAKE L., HUAIEN L., SHEN B., YAJIAO L. Effect of non-point source pollution on water quality of the weihe river. International Journal of Sediment Research, 26 (1), 50, 2011.

13. SUN Z. C., QIAN H., MENG X.Y. The Spatial and Temporal Characteristics Analysis of the Ammonia Nitrogen Pollution in the Shaanxi Section of Weihe River. Journal of North China University of Water Resources and Electric Power (Natural Science Edition), 36 (5), 81. 2015 [In Chinese]

14. DONG W., ZHANG Z.W., SUN C.S., LI HUAI-EN. Nitrogen Pollution of Weihe River During 1996-2009. Bulletin of Soil and Water Conservation, 34 (5), 114, 2014 [In Chinese].

15. GUO W., SHENG Y. Analysis and Prediction of the COD Discharge in the Weihe River Basin of Guanzhong Area. Yellow River, 35 (7), 66, 2013 [In Chinese].

16. ZHANG T., SONG J., YANG X.G., CHEN J, CHENG D.D.. Study on the temporal-spatial distribution characteristics and influencing factors of TP and TN in river sediments for the Weihe River of Shaanxi Province. Acta Scientiae Circumstantiae, 35 (5), 1393, 2015 [In Chinese]. 
17. WANG H., LI H.E., WANG L.. Analysis of relationship between water quality and flow in Fenghe River. Journal of Water Resources-Water Engineering, 23 (6), 83, 2012 [In Chinese].

18. D.P. ZUO, Z.Z. XU, D.Z. PENG J.X. SONG L., CHENG S. K. WEI, KARIM C. A., H. YANG. Simulating spatiotemporal variability of blue and green water resources availability with uncertainty analysis. Hydrological Processes, 29 (8), 1942, 2014.

19. ZHAO A., ZHU X., LIU X., PAN Y., ZUO D. Impacts of land use change and climate variability on green and blue water resources in the weihe river basin of northwest china. Catena, 137, 318, 2016.

20. LIU L.S. River Water Quality Assessment Analysis based on Principal Component Analysis Method. Heilongjiang Hydraulic Science and Technology, 44, 59, 2016 [In Chinese].

21. JIN C.H., LI Z.R., SHENG Y.Q. Influxes of COD in Coastal Rivers around the Bohai Sea and their Contribution for total COD Capacity in the Bohai Sea. China Environmental Science, 36, 1835, 2016 [In Chinese].

22. ZHANG H., LIN C., LEI P., SHAN B.Q., ZHAO Y. Trends of pollution by the oxygen-consuming substances and the distribution of oxygen deficiency in the Haihe River Basin. Acta Scientiae Circumstantiae, 35, 2324, 2015 [In Chinese].

23. BAI Y., JIA X.Y., DING H., QIN H.P. Introduction of COD method for the mensuration of waste water by sealed digestion method. Anhui chemical, 94, 35, 1998 [In Chinese].

24. TANG S.J., SHI L., ZHAO Y.C. Research Progress of COD Determination Methods. Sichuan Environment, 24, 40, 2005 [In Chinese]

25. LIN Y.L., CAI X.G., JI Z.Y., XU X.Y. Research on Influence Factors of Ammonia Nitrogen Determination after Water Sample Pretreatment. CHINA WATER\&WASTEWATER, 32, 89, 2016 [In Chinese].

26. DEHGHAN M., MOHAMMADI V. Error analysis of method of lines (mol) via generalized interpolating moving least squares (gimls) approximation. Journal of Computational \& Applied Mathematics, 321, 540, 2017.

27. SHIRIN M., MAHMOUD R.S., ALIREZA N. New model for prediction binary mixture of antihistamine decongestant using artificial neural networks and least squares support vector machine by spectrophotometry method. Spectrochimica Acta Part A: Molecular and Biomolecular Spectroscopy, 182 (5), 105, 2017.

28. ZHAO W., FAN F., WANG W. Non-linear partial least squares response surface method for structural reliability analysis. Reliability Engineering \& System Safety, 161, 69, 2017.

29. YUSUKE H., MAKOTO O. Modeling of feed-forward control using the partial least squares regression method in the tablet compression process. International Journal of Pharmaceutics, 524 (1-2), 407, 2017.

30. LV Q., XIAO Z.P., JI J., ZHENG J., SHANG Y.Q. Moving least squares method for reliability assessment of rock tunnel excavation considering ground-support interaction. Computers \& Geotechnics, 84, 88, 2017.

31. JERRY R. MILLER, SUZANNE M. ORBOCK MILLER, Contaminated rivers, 2007.

32. WANG Z., SONG J.X., DUAN M.C., REN C.L.. Characteristic analysis of COD and NH3-N change of water quality in Shaanxi section of Weihe River. Journal of Water Resources \& Water Engineering, 24 (3), 64, 2013 [In Chinese].
33. LI P., XIANG T.J., HOU S.M., WANG F., WEN S.E., REN H.L.. Evaluation of Water Environmental Quality of the Weihe River in Shaanxi Province. Journal of Weinan Normal University, 30, 40, 2015 [In Chinese].

34. YANG F., JIANG Y.F., WANG C.C., HUANG X.N., WU Z.Y., CHEN L. Characteristics of Nitrogen and Phosphorus Losses in Longhong Ravine Basin of Westlake in Rainstorm Runoff. Environmental Science, 37 (1), 141, 2016 [In Chinese].

35. YU B., HUANG C.M., LIU Z.H., ZHANG B., QIN F.C. Wavelet analysis on nh3-n pollution index changes of the middle-upper minjiang river during last 6 years. Procedia Environmental Sciences, 2 (1), 9, 2010.

36. PENG F.J., PAN C.G., ZHANG M., ZHANG N.S., WINDFELD R., SALVTO D., SELCK H., VAN B.P. Occurrence and ecological risk assessment of emerging organic chemicals in urban rivers: guangzhou as a case study in china. Science of the Total Environment, 589, 46, 2017.

37. ANNA M.D.G., RAFFAELLA B., ERSILIA D., GIUSEPPE P., ELISA S., ANTONIO L.P. Antropogenic input of nitrogen and riverine export from a Mediterranean catchment. The Celone, a temporary river case study. Agricultural Water Management, 187, 190, 2017.

38. ZHANG J.L., ZHENGB.H., LIU L.S., WANG L.P., HUANG, M.S., WU G.Y. Seasonal variation of phytoplankton in the daning river and its relationships with environmental factors after impounding of the three gorges reservoir: a four-year study. Procedia Environmental Sciences. 2 (6), 1479, 2010.

39. CUI J., ZHOU J., PENG Y., YANG H., HE Y. Q. Inorganic $\mathrm{n}$ of atmospheric wet deposition from a typical agro-ecosystem in southeast china during rainy season. Procedia Engineering. 18, 95, 2011.

40. HE Y.F., LI H.C., ZHU Y.J., YANG D.G. Status and Spatialtemporal Variations of Eutrophication in Lake Changhu, Hubei Province. Journal of Lake Sciences, 27, 853, 2015 [In Chinese].

41. YANG H.J., SHEN Z.M., ZHANG J.P., WANG W.H. Water quality characteristics along the course of the huangpu river (china). Journal of Environmental Sciences, 19 (10), 1193, 2007.

42. AMNEEA W.A., NAJIB N.W.A.Z., MOHD Y., S.R., RAGUNATHAN S. Water quality index of perlis river, malaysia. International Journal of Civil \& Environmental Engineering, 13 (2), 1, 2013.

43. ZHEN S., NA X., MIN W. Empirical analysis on economic losses of urban river pollution-a case study of changzhou city of jiangsu province. Energy Procedia, 5, 2010, 2011.

44. ŞENER Ş., ŞENER E., DAVRAZ A. Evaluation of water quality using water quality index (wqi) method and gis in aksu river (sw-turkey). Science of the Total Environment, 15, 131, 2017.

45. ABDEL A.M., MH A., ME G. Indices of water quality and metal pollution of nile river, egypt. Egyptian Journal of Aquatic Research, 43 (1), 21, 2017.

46. GUAN X., LIU W., CHEN M. Study on the ecological compensation standard for river basin water environment based on total pollutants control. Ecological Indicators, 69, 446, 2016.

47. FAN X., CUI B., ZHAO H., ZHANG Z., ZHANG H. Assessment of river water quality in pearl river delta using multivariate statistical techniques. Procedia Environmental Sciences, 2 (6), 1220, 2010. 